\title{
KEABSAHAN PENUNJUKAN PELAKSANA TUGAS DIREKSI OLEH DEWAN KOMISARIS UNTUK MENGISI JABATAN ANGGOTA DIREKSI YANG LOWONG PADA BUMN (PERSERO)
}

\author{
Lutria Mira Sari \\ Fakultas Hukum, Universitas Brawijaya, Indonesia \\ Email: lutriamohammadsofie@gmail.com
}

\begin{abstract}
Abstrak
Penelitian ini bertujuan untuk menganalisis keabsahan penunjukan pelaksana tugas Direksi oleh Dewan Komisaris untuk mengisi jabatan anggota Direksi yang lowong pada BUMN seperti yang terjadi dalam PT. Angkasa Pura (Persero) dimana dalam Anggaran Dasar mengatur hal yang sepertinya berbeda dengan ketentuan Undang-Undang terkait, dan apakah ada pertentangan antara aturan dalam Undang-Undang 19 Tahun 2003 tentang BUMN, Undang-Undang Nomor 40 Tahun 2007 tentang Perseroan Terbatas dengan Anggaran Dasar tersebut. Metode penelitian yang digunakan adalah metode penelitian hukum normatif dengan menggunakan pendekatan perundang-undangan dan pendekatan konsep. Berdasarkan hasil penelitian Perseroan Terbatas yang sahamnya sepenuhnya dimiliki oleh Badan Usaha Milik Negara (BUMN), selanjutnya disebut Persero, dalam kegiatannya selain merujuk pada Undang-Undang Nomor 40 Tahun 2007 dan UndangUndang Nomor 19 Tahun 2003 tentang BUMN. Namun dalam anggaran dasar PT. Angkasar Pura mengatur hal yang berbeda yaitu dapat diangkat oleh Direksi dalam hal jika RUPS belum dilaksanakan.
\end{abstract}

Kata Kunci: Direksi; Perseroan Terbatas; Badan Usaha Milik Negara.

\begin{abstract}
Abtract
This study aims to analyze the validity of the appointment of the executor of the duties of the Board of Directors by the Board of Commissioners to fill the positions of the members of the Board of Directors who are vacant in BUMN as happened in PT. Angkasa Pura (Persero), which in the Articles of Association regulates things that seem different from the provisions of the relevant Law, and is there a conflict between the rules in Law 19 of 2003 concerning BUMN, Law Number 40 of 2007 concerning Limited Liability Companies and the Articles of Association the. The research method used is a normative legal research method using a statutory approach and a conceptual approach. Based on the results of research on Limited Liability Companies whose shares are fully owned by State-Owned Enterprises (BUMN), hereinafter referred to as Persero, in their activities other than referring to Law Number 40 of 2007 and Law Number 19 of 2003 concerning BUMN. However, in the articles of association of PT. Angkasar Pura regulates different things, namely that it can be appointed by the Board of Directors in the event that the GMS has not been held.
\end{abstract}

Keywords: Directors; Limited company; State-owned Enterprises.

\section{A. PENDAHULUAN}

Kedudukan Perseroan Terbatas sebagai persona standi in judicio, yang berarti meskipun perseroan terbatas berwujud suatu badan atau organisasi, dan bukan manusia secara alamiah, namun dimata hukum, Perseroan Terbatas dipandang sama seperti manusia alamiah yang dapat menjadi pendukung hak dan kewajiban. Organ Perseroan Terbatas terdiri dari: Rapat Umum Pemegang saham (RUPS); Dewan Komisaris; dan Direksi. Ketiga organ tersebut memiliki

144 Lutria Mira Sari | Keabsahan Penunjukan Pelaksana Tugas ... 
wewenang dan peran masing-masing, yang diatur dalam Undang-undang Nomor 40 tahun 2007 tentang Perseroan Terbatas yang selanjutnya disingkat UUPT.

Direksi merupakan organ yang sangat penting dalam suatu perseroan terbatas, direksi dapat diibaratkan sebagai nahkoda pada sebuah kapal yang berlayar, sebab maju dan mundurnya satu perseroan terbatas sangat bergantung pada setiap keputusan-keputusan yang dibuat oleh Direksi. Menurut ketentuan UUPT, direksi dipercaya sebagai organ yang berhak mengurus perseroan terbatas. Fungsi direksi dalam hal pengurusan Perseroan Terbatas diatur dalam Pasal 1 ayat (5) UUPT, Pasal 92 ayat (1) dan ayat (2) UUPT, serta Pasal 97 ayat (1) UUPT. Selain itu, direksi juga berfungsi sebagai perwakilan perseroan terbatas, yang artinya setiap tindakan untuk dan atas nama perseroan diwakilkan olehnya, dimana perwakilan tersebut baik tindakan kedalam ataupun tindakan keluar yang berkaitan dengan pihak ketiga, termasuk mewakili perseroan terbatas dalam Pengadilan, sehingga dengan demikian setiap gerakan atau aktivitas direksi Perseroan Terbatas juga merupakan kehendak dari Perseroan Terbatas itu sendiri, yang mana kehendak badan hukum itu dapat dilihat pada tujuan berdirinya dan amanat pemegang saham dalam rapat umum yang termaktub dalam anggaran dasar. ${ }^{1}$

Berdasarkan ketentuan Pasal 94 ayat (1) UUPT, anggota direksi diangkat oleh Rapat Umum Pemegang Saham (RUPS), dimana RUPS merupakan organ perseroan yang mempunyai wewenang yang tidak diberikan kepada Direksi atau Dewan Komisaris dalam batas yang ditentukan dalam UUPT dan dalam anggaran dasar perseroan. Dengan demikian berdasarkan ketentuan yang diatur dalam Pasal 94 ayat (1) UUPT tersebut, pengangkatan direksi wajib melalui keputusan RUPS, yang mana wewenang tersebut tidak dapat dilimpahkan atau diganti oleh organ-organ perseroan lainnya.

Pembentukan organ perusahaan Badan Usaha Milik Negara (BUMN) berbentuk Perseroan Terbatas, berdasarkan ketentuan Pasal 11 Undang-Undang Nomor 19 Tahun 2003 tentang Badan Usaha Milik Negara, selanjutnya disebut UU BUMN, berlaku juga segala ketentuan dan prinsip-prinsip yang berlaku bagi perseroan terbatas sebagaimana diatur dalam UndangUndang Nomor 1 Tahun 1995 tentang Perseroan Terbatas (yang telah diubah dengan UndangUndang Nomor 40 Tahun 2007 tentang Perseroan Terbatas), dengan demikian mekanisme pengangkatan dan pemberhentian Direksi juga mengikuti ketentuan yang diatur dalam UUPT.

Berdasarkan ketentuan Pasal 15 ayat (1) UU BUMN, dinyatakan bahwa pengangkatan dan pemberhentian direksi dilakukan oleh RUPS. Pengangkatan direksi tersebut juga diatur dalam Peraturan Pemerintah Republik Indonesia No. 45 Tahun 2005 tentang Pendirian, Pengurusan, Pengawasan, dan Pembubaran Badan Usaha Milik Negara yang merupakan peraturan pelaksanaan atas Undang-Undang Nomopr 19 Tahun 2003 tentang Badan Usaha Milik Negara.

Pada Pasal 19 PP 45 Tahun 2005 menyebutkan bahwa anggota direksi diangkat untuk masa jabatan 5 (lima) tahun dan dapat diangkat kembali untuk 1 (satu) kali masa jabatan, ayat (2) menyebutkan apabila masa jabatan anggota direksi berakhir, maka dalam waktu selambatlambatnya 30 (tiga puluh) hari sejak masa jabatan tersebut berakhir, RUPS untuk Persero dan Menteri untuk Perum sudah harus menetapkan anggota Direksi yang definitif, kemudian pada ayat (3) menyebutkan dalam anggaran dasar diatur ketentuan mengenai pengisian sementara jabatan Direksi yang kosong atau dalam hal direksi diberhentikan sementara atau berhalangan.

Pasal tersebut emberikan kesempatan kepada BUMN berbentuk PT, khususnya PT yang seluruh sahamnya dimiliki oleh BUMN, untuk mengatur pelaksanaan pengangkatan direksi yang lowong dalam anggaran dasarnya. Anggaran dasar pada suatu perseroan berperan sangat penting dalam pelaksanaan perseroan, karena anggaran dasar tersebut berfungsi sebagai ramburambu dan acuan para organ perseroan dalam bertindak melakukan fungsi dan perannya sesuai

$1 \quad$ Freddy harris, Teddy Anggoro.(2010). Hukum Perseroan Terbatas: Kewajiban Pemberitahuan oleh Direksi. Bogor: Ghalia Indonesia, hlm 37. 
maksud dan tujuan perseroan. Pentingnya Anggaran Dasar pada suatu perseroan BUMN, juga harus tunduk pada peraturan perundang-undangan yang mengaturnya, dalam hal ini UndangUndang BUMN dan Undang-Undang Perseroan Terbatas.

Seperti contoh, dalam Anggaran Dasar PT Angkasa Pura (Persero), yang merupakan perusahaan yang sahamnya sepenuhnya dimiliki oleh BUMN, diatur mekanisme pengangkatan direksi lowong, yang merujuk pada Pasal 19 ayat (3) PP No. 45 Tahun 2005. Anggaran Dasar PT Angkasa Pura (Persero) Pasal 10 ayat (26) diatur mekanisme pengangkatan direksi yang lowong sebagai berikut:

Apabila oleh suatu sebab jabatan anggota Direksi Perseroan lowong, maka:

a. Dalam waktu paling lambat 30 (tiga puluh) hari setelah terjadi kekosongan jabatan tersebut, wajib diselenggarakan Rapat Umum Pemegang Saham untuk mengisi jabatan anggota Direksi yang lowong tersebut.

b. Selamajabatanitu lowong dan Rapat Umum Pemegang Sahambelum mengisi jabatan anggota direksi yang lowong sebagaimana dimaksud pada huruf a ayat ini, maka dewan komisaris menunjuk salah seorang anggota direksi lainnya atau RUPS menunjuk pihak lain selain anggota direksi yang ada, untuk sementara menjalankan pekerjaan anggota direksi yang lowong tersebut dengan kekuasaan dan wewenang yang sama.

Berdasarkan Anggaran Dasar tersebut di atas, khususnya pasal 10 ayat (26) b. terdapat kalimat “...maka dewan komisaris menunjuk salah seorang anggota direksi lainnya atau RUPS menunjuk pihak lain selain anggota direksi yang ada... dst". Hal tersebut dapat diartikan bahwa untuk mengisi jabatan direksi yang lowong, dapat dilakukan dengan cara Dewan komisaris menunjuk salah seorang anggota direksi lainnya, atau RUPS menunjuk pihak lain selain anggota direksi yang ada.

Jika terdapat anggota Direksi yang lowong, misalnya disebabkan karena anggota Direksi tersebut melaksanakan: cuti tahunan; melaksanakan ibadah haji; melaksanakan tugas ke luar negeri; atau karena keadaan apapun yang menyebabkan kosongnya jabatan anggota direksi; maka berdasarkan anggaran dasar PT Angkasa Pura (Persero) Pasal 10 ayat (26.b) Dewan Komisaris dapat melaksanakan rapat komisaris untuk kemudian menetapkan anggota Direksi lain untuk mengisi jabatan direksi yang lowong. Direksi yang mengisi jabatan yang lowong tersebut disebut Pelaksana Tugas (Plt Direksi), dan dapat melakukan seluruh tindakan dengan kekuasaan dan wewenang yang sama dengan anggota Direksi yang digantikannya.

Isu ini menjadi menarik untuk diteliti, karena terdapat perbedaan ketentuan yang berlaku pada Undang-Undang No.40 tahun 2007 tentang Perseroan Terbatas, UU Nomor 19 tahun 2003 tentang BUMN, dan PP No.45 tahun 2005 tentang Pendirian, Pengurusan, Pengawasan, dan Pembubaran BUMN dengan Anggaran Dasar Perseroan PT Angkasa Pura (Persero). Sehingga terdapat ketidaksesuaian antara apa yang terjadi pada praktik pengangkatan Direksi khususnya dalam hal pengakatan direksi yang posisinya lowong dalam suatu BUMN berbentuk PT dengan ketentuan peraturan perundang-undangan yang berlaku.

Berdasarkan uraian tersebut, maka dapat dirumuskan permasalahan: Apakah pengangkatan Pelaksana Tugas Direksi PT. Angkasa Pura oleh Dewan Komisaris pada BUMN Persero bertentangan dengan Pasal 94 ayat (1) Undang-Undang Nomor 40 tahun 2007 tentang Perseroan Terbatas dan apa akibat hukum atas pengangkatan Pelaksana Tugas Direksi yang diangkat oleh Dewan Komisaris pada BUMN Persero berdasarkan ketentuan pada anggaran dasar perseroan?

\section{B. METODE PENELITIAN}

Jenis penelitian yang dipergunakan oleh penulis adalah penelitian hukum normatif, yang pada hakikatnya menekankan pada metode deduktif sebagai pegangan utama dan metode

146 Lutria Mira Sari | Keabsahan Penunjukan Pelaksana Tugas ... 
induktif sebagai tata kerja penunjang. Kaitannya penggunaan analisis normatif dalam penelitian ini, karena terjadinya konflik norma antara peraturan pelaksanaan pengangkatan direksi sebagaimana diatur dalam Undnag-Undang BUMN dan Undang-Undang Perseroan Terbatas dengan pelaksanaan pengangkatan direksi pelaksana sebagaimana datur dalam Angaran dasar PT Angkasa Pura. Analisis normatif terutama mempergunakan bahan-bahan kepustakaan sebagai sumber data penelitiannya. ${ }^{2}$

\section{PEMBAHASAN}

\section{Pengangkatan Pelaksana Tugas (Plt.) Direksi Oleh Dewan Komisaris PT. Angkasa Pura Dikaitkan Dengan Pasal 94 ayat (1) Undang-Undang Nomor 40 Tahun 2007 Tentang Per- seroan Terbatas.}

Teori organ menyatakan bahawa badan hukum memiliki pemikiran yang benar benar riil, kehendak yang benar-benar riil, dan juga kewenangan yang benar-benar riil ${ }^{3}$ maka dengan kata lain teori organ menjelaskan bahwa badan hukum itu terbentuk dan bisa memenuhi kehendaknya sendiri melalui kepengurusan-kepengurusan yang dilakukannya sendiri, dengan demikian hal tersebut sama seperti halnya organ tubuh pada manusia, contoh: kepengurusan ketua atau direktur utama pada badan hukum sama seperti halnya kepala pada manusia, dan berlaku juga untuk organ-organ lain dalam badan hukum yang dapat dipersamakan dengan organ-organ pada tubuh manusia yang pada intinya menjalankan kegiatannya secara nyata sesuai dengan kehendaknya sendiri.

Pasal 94 ayat (1) Undang-Undang nomor 40 Tahun 2007 tentang Perseroan Terbatas (UUPT) mengatur bahwa direksi diangkat oleh Rapat Umum Pemegang Saham (RUPS) yang mana RUPS merupakan salah satu organ perseroan tertinggi yang kedudukannya tidak dapat diserahkan kepada organ lainnya. Hal tersebut secara jelas dinyatakan dalam Pasal 75 ayat (1) UUPT yang bunyinya: "RUPS mempunyai wewenang yang tidak diberikan kepada Direksi atau Dewan Komisaris dalam batas wewenang yang diberikan undang-undang ini dan/atau anggaran dasar". Pasal 94 ayat (1) tersebut telah secara tegas menetapkan bahwa Anggota Direksi diangkat oleh RUPS.

Badan Usaha Milik Negara merupakan salah satu pelaku kegiatan ekonomi dalam perekonomian nasional berdasarkan demokrasi ekonomi. Pengaturan mengenai BUMN telah mengalami beberapa perubahan dan yang berlaku saat ini adalah Undang-Undang No 19 tahun 2003 tentang Badan Usaha Milik Negara. Menurut Undang-Undang No 19 tahun 2003 tentang Badan Usaha Milik Negara (UU BUMN) pasal 1 ayat (1) menyebutkan bahwa Badan Usaha Milik Negara, yang selanjutnya disebut BUMN, adalah badan usaha yang seluruh atau sebagian besar modalnya dimiliki oleh negara melalui penyertaan secara langsung yang berasal dari kekayaan negara yang dipisahkan.

Pengurusan dan pengawasan perseroan BUMN dilakukan secara cermat dan hati-hati, dengan membuat peraturan pelaksana sebagaimana diatur dalam Peraturan Pemerintah No.45 tahun 2005 tentang Pendirian, Pengurusan, Pengawasan, dan Pembubaran BUMN, serta Anggaran Dasar Perusahaan.

Berdasarkan ketentuan Pasal 11 UU BUMN berbentuk Persero berlaku segala ketentuan dan prinsip-prinsip yang berlaku bagi perseroan terbatas sebagaimana diatur dalam UndangUndang Nomor 1 tahun 1995 tentang Perseroan Terbatas yang kemudian diubah menjadi Undang-Undang Nomor 40 tahun 2007 tentang Perseroan Terbatas.

\footnotetext{
${ }^{2}$ Amiruddin \& Zainal Asikin.(2006). Pengantar Metode Penelitian Hukum. Jakarta: Raja Grafindo Persada, hlm. 166 ${ }^{3}$ Ibid, hlm. 193.
} 
Di dalam Teori organ, penulis mengambil pendapat Von Savigny yang berpandangan bahwa keberadaan suatu badan hukum adalah karena dia memang benar-benar ada dalam masyarakat bukan fiksi, yang mana dinyatakan bahawa badan hukum memiliki pemikiran yang benarbenar riil, kehendak yang benar-benar riil, dan juga kewenangan yang benar-benar riil ${ }^{4}$ maka dengan kata lain teori organ menjelaskan bahwa badan hukum itu terbentuk dan bisa memenuhi kehendaknya sendiri melalui kepengurusan-kepengurusan yang dilakukannya sendiri. hal ini sesuai dengan adanya organ-organ dalam suatu perseroan terbatas.

Dengan diberlakukannya prinsip-prinsip dalam Undang-Undang PT pada perseroan BUMN maka dengan demikian, organ-organ yang terdapat dalam BUMN berbentuk Persero sama dengan organ-organ yang dikenal dalam Perseroan Terbatas, hal tersebut juga diatur didalam Pasal 13 UU BUMN yaitu: RUPS; Direksi; dan Dewan Komisaris.

Kewenangan dapat dipersamakan dengan kekuasaan. Kekuasaan biasanya berbentuk hubungan dalam arti bahwa ada satu pihak yang memerintah dan pihak lain yang diperintah. ${ }^{5}$ Kekuasaan yang berkaitan dengan dengan hukum pada umumnya dikenal sebagai wewenang rasional atau legal yang dipopulerkan oleh Max Weber, yang mana arti dari teori kewenangan tersebut disaring sebagai wewenang rasional atau legal, yaitu wewenang yang disandarkan pada sistem hukum yang berlaku dalam masyarakat, sistem hukum mana yang dipahamkan sebagai kaidah-kaidah yang telah diakui serta ditaati oleh masyarakat, dan bahkan diperkuat oleh negara ${ }^{6}$.

Kewenangan harus dilandasi oleh ketentuan hukum yang ada, sehinga kewenangan tersebut merupakan kewenangan yang sah, dengan demikian organ perusahaan dalam menjalankan tugas dan/atau mengeluarkan keputusan didukung oleh sumber kewenangan tersebut. Kewenangan diperoleh oleh suatu organ dengan cara atribusi, delegasi dan mandat. Tanpa kewenangan tidak dapat dikeluarkan suatu keputusan yuridis yang benar. ${ }^{7}$

Dalam melakukan tugas dan wewenangnya Dewan Komisaris harus bekerja secara independen untuk kepentingan perseroan sesuai maksud dan tujuan perseroan. Dewan Komisaris bersifat majelis, setiap anggota tidak dapat bertindak secara sendiri-sendiri, setiap tindakan harus berdasarkan rapat atau keputusan kolektif seluruh dewan komisaris. Dari ketentuan pasal tersebut, tampak bahwa Dewan Komisaris sebagai lembaga pengawas dalam menjalankan tugasnya harus mengacu kepada maksud dan tujuan perseroan. Penekanan seperti ini tentu punya alasan sebab salah satu karakterisitik PT sebagai badan hukum adalah memunya tujuan dan kepentingan sendiri. ${ }^{8}$ Berdasarkan ketentuan Pasal 27 UU BUMN, Komisaris diangkat dan diberhentikan oleh Rapat Umum Pemegang Saham (RUPS), dan dalam hal Menteri selaku RUPS, maka pengangakan dan pemberhentiannya ditetapkan oleh Menteri, untuk jangka waktu 5 (tahun) dan dapat dipepanjang 1(satu) kali masa jabatan.

Sesuai ketentuan Pasal 15 ayat (1) UU BUMN, dinyatakan bahwa pengangkatan dan pemberhentian direksi dilakukan oleh RUPS, sehingga dengan demikian RUPS pada BUMN berbentuk PT juga sebagai organ yang mana memiliki kewenangan yang tidak dapat diserahkan kepada organ lainnya khususnya dalam hal pengangkatan direksi. Pengangkatan direksi tersebut juga diatur dalam Peraturan Pemerintah Republik Indonesia No. 45 Tahun 2005 tentang Pendirian, Pengurusan, Pengawasan, dan Pembubaran Badan Usaha Milik Negara selanjutnya disebut PP BUMN, yang merupakan peraturan pelaksanaan atas UU BUMN.

\footnotetext{
${ }^{4}$ Ibid., hlm. 193.

${ }^{5}$ Miriam Budiarjo.(1998). Dasar-dasar ilmu politik. Jakarta: Gramedia Pustaka Utama, hlm. 35-36.

${ }^{6}$ Salim dan Nurbani.(2013). Penerapan Teori Hukum Pada Penelitian Tesis dan Desertasi. Depok: Rajagrafindo Persada, hlm. 187.

${ }^{7}$ Abdul Rasyid Thalib.(2006). Wewenang Mahkamah Konstitusi dan Aplikasinya dalam sistem ketatanegaraan Republik Indonesia. Bandung: Citra Aditya Bakti, hlm. 219

${ }^{8}$ Claudia Brigita Kilis.(2015). Tanggung Jawab Dewan Komisaris PT dalam melaksanakan pengawasan terahdap Direksi menurut Undang-Undang no. 40 tahun 2007, Manado: Jurnal Universitas Sam Ratulangi, hlm. 4
}

148 Lutria Mira Sari | Keabsahan Penunjukan Pelaksana Tugas ... 
Pasal 19 PP BUMN diatur mengenai Petunjuk Pelaksanaan UU BUMN yang menetapkan mengenai pengangkatan direksi. Dengan adanya ketentuan Pasal 19 ayat (3) PP BUMN yang telah disebutkan di atas, maka memberikan kesempatan kepada BUMN berbentuk PT untuk mengatur pelaksanaan pengangkatan direksi yang lowong pada anggaran dasarnya.

Anggaran dasar pada suatu perseroan berperan sangat penting dalam pelaksanaan perseroan, karena anggaran dasar tersebut berfungsi sebagai rambu-rambu dan acuan para organ perseroan dalam bertindak melakukan fungsi dan perannya sesuai maksud dan tujuan perseroan. Pentingnya Anggaran Dasar pada suatu perseroan, juga harus tunduk pada peraturan perundang-undangan yang mengaturnya, dalam hal ini yaitu UUPT, UU BUMN dan PP BUMN, hal tersebut demi terciptanya keserasian dan keselarasan antara peraturan yang satu dengan peraturan terakit lainnya, sehingga pelaksanaan perseroan terhindar dari resiko masalah hukum.

Pada praktiknya dalam anggaran dasar PT Angkasa Pura, yang seluruh sahamnya dimiliki oleh BUMN, diatur mekanisme pengangkatan direksi lowong sebagaimana diatur dalam Pasal 19 ayat (3) PP BUMN. Pada Anggaran Dasar PT Angkasa Pura yaitu pada Pasal 10 ayat (26.b) diatur mekanisme pengangkatan direksi yang lowong sebagai berikut: selama jabatan itu lowong dan Rapat Umum Pemegang Saham belum mengisi jabatan anggota direksi yang lowong sebagaimana dimaksud pada huruf a ayat ini, maka dewan komisarisnya menunjuk salah seorang anggota direksi lainnya atau RUPS menunjuk pihak lain selain anggota direksi yang ada, untuk sementara menjalankan pekerjaan anggota direksi yang lowong tersebut dengan kekuasaan dan wewenang yang sama.

Tegasnya dalam kondisi di atas bahwa pengangkatan Direksi perseroan yang lowong dimungkinan untuk diangkat oleh selain RUPS, yaitu oleh Dewan Komisaris, sedangkan berdasarkan ketentuan UUPT, UU BUMN, dan UU PP BUMN dinyatakan dengan tegas bahwa pengangkatan direksi hanya dapat dilakukan melalui RUPS, sehingga keabsahan pengangkatan anggota direksi hanya melalui keputusan RUPS, sebagai organ yang memegang kekuasaan tertinggi dimana kekuasaan dan wewenang tersebut tidak dapat diwakilkan atau dilimpahkan kepada organ lainnya, dalam hal ini Dewan Komisaris sekalipun.

Dalam pelaksanaannya dalam PT Angkasa Pura, jika terdapat anggota Direksi yang lowong, misalnya disebabkan karena anggota Direksi tersebut melaksanakan cuti tahunan, melaksanakan ibadah haji, melaksanakan tugas ke luar negeri, atau karena keadaan apapun yang menyebabkan kosongnya jabatan anggota direksi, maka berdasarkan ketentuan anggaran dasar PT Angkasa Pura yang terdapat pada Pasal 10 ayat (26.b) Dewan Komisaris dapat melaksanakan rapat komisaris untuk kemudian menetapkan anggota Direksi lain untuk mengisi jabatan direksi yang lowong tersebut. Direksi ytang mengisi kelowongan jabatan tersebut disebut sebagai Pelaksana Tugas (Direksi Plt), dan dapat melakukan seluruh tindakan dengan kekuasaan dan wewenang yang sama dengan anggota Direksi yang digantikannya tersebut.

Pembentukan Peraturan Perundang-Undangan diatur pada Undang-Undang Nomor 12 Tahun 2011 tentang Pembentukan Peraturan Perundang-Undangan. Pada pasal 7 disebutkan bahwa:

(1) Jenis dan hierarki Peraturan Perundang-undangan terdiri atas:
a. Undang-Undang Dasar Negara Republik Indonesia Tahun 1945;
b. Ketetapan Majelis Permusyawaratan Rakyat;
c. Undang-Undang/Peraturan Pemerintah Pengganti Undang-Undang;
d. Peraturan Pemerintah;
e. Peraturan Presiden;
f. Peraturan Daerah Provinsi; dan
g. Peraturan Daerah Kabupaten/Kota. 
(2)Kekuatan hukum Peraturan Perundang-undangan sesuai dengan hierarki sebagaimana dimaksud pada ayat (1).

Berdasarkan uraian di atas, terdapat pertentangan antara peraturan hukum yang satu dengan yang lainnya terkait pengangkatan direksi dalam perseroan milik BUMN, yaitu ketentuan yang berlaku di dalam Undang-Undang No.40 tahun 2007 tentang Perseroan Terbatas, UndangUndang Nomor 19 tahun 2003 tentang BUMN, dan Peraturan Pemerintah No.45 tahun 2005 tentang Pendirian, Pengurusan, Pengawasan, dan Pembubaran BUMN, dengan Anggaran Dasar Perseroan PT Angkasa Pura (Persero). Anggaran Dasar suatu perusahaan merupakan suatu perjanjian yang dibentuk berdasarkan petunjuk dari peraturan pemerintah. Dengan demikian peraturan yang terdapat didalam Anggaran Dasar tidak boleh bertentangan dengan peraturan yang ada diatasnya. Dengan demikian sesuai dengan asas Lex superior derogat leg inferior yang menyatakan bahwa hukum yang lebih tinggi (lex superior) mengesampingkan hukum yang rendah (leg inferior) sehingga menurut penulis apabila ada perbedaaan pengaturan dalam suatu Anggaran Dasar dengan peraturan Perundang-undangan maka yang berlaku adalah Peraturan Perundang-Undangan.

Dengan terjadinya perbedaan pelaksanaan peraturan pengangkatan direksi tersebut, maka pengangkatan direksi pelaksana yang diangkat oleh dewan komisaris bertentangan dengan ketentuan peraturan yang ada. Oleh karena itu, Komisaris berpotensi melakukan ultra vires, yaitu melakukan kegiatan melampaui kewenangannya ${ }^{9}$, sehingga dapat dikategorikan melanggar UU PT Pasal 97 dan 114. Oleh karena itu, Penulis berpendapat bahwa proses pengangkatan Plt. Direksi oleh Komisaris, untuk mengisi jabatan yang lowong tersebut, tidak sah.

Berdasarkan uraian diatas, menurut analisis penulis pengangkatan pelaksana tugas (plt.) direksi oleh dewan komisaris PT ANGKASA PURA yang didasarkan pada Anggaran Dasar Perserroan tersebut bertentangan dengan Pasal 94 ayat (1) Undang-Undang Nomor 40 Tahun 2007 tentang Perseroan Terbatas, yang menyatakan bahwa anggota Direksi diangkat oleh RUPS.

\section{Akibat Hukum Dari Pengangkatan Pelaksana Tugas Direksi Yang Diangkat Oleh De- wan Komisaris Berdasarkan Ketentuan Pada Anggaran Dasar Perseroan.}

\section{a. Akibat Hukum Perbuatan PIt Direksi yang diangkat oleh Dewan Komisaris terhadap Pihak Ketiga.}

Tidak sahnya Plt. Direksi yang diangkat oleh dewan komisaris ini, kemudian mengakibatkan ketidakpastian hukum atas segala perbuatan hukum yang dilakukan oleh pelaksana tugas direksi yang diangkat oleh dewan komisaris tersebut termasuk perbuatan hukumnya dalam mewakili perseroan dengan pihak ketiga.

Dalam hal PT Angkasa Pura mengadakan perjanjian dengan pihak ketiga, dimana Plt Direksi sebagai wakil dari PT Angkasa Pura sedangkan pengangkatan Plt Direksi tersebut sebenarnya melanggar hukum maka mengakibatkan Plt Direksi tersebut bukanlah orang yang berwenang mewakili PT Angkasa Pura dalam melakukan perjanjian.

Pada dasarnya sahnya suatu perjanjian yaitu saat perjanjian tersebut telah memenuhi syarat Subjektif dan Syarat Objektif sahnya suatu perjanjian. Syarat-syarat tersebut diatur dalam Pasal 1320 KUHPerdata yang memberikan penjelasan mengenai syarat sahnya perjanjian, yaitu: Sepakat, Cakap (Syarat Subyektif), Hal tertentu dan kausa yang halal (syarat obyektif).

Apabila syarat objektif sahnya perjanjian tidak terpenuhi maka perjanjian tersebut menjadi batal demi hukum. Artinya sejak semula perjanjian tersebut dianggap tidak pernah ada dan tidak ada perikatan apapun diantara para pihak. Batal demi hukum atau tidaknya sautu perjanjian

\footnotetext{
${ }^{9}$ Nyulistyowati Suryani.(2015). Hukum Perusahaan. Jakarta: Karunika, hlm. 26.
} 
harus berdasarkan keputusan hakim yang menyatakan bahwa perjanjian tersebut batal demi hukum dan tidak pernah ada perikatan yang terjadi diantara para pihak.

Tidak terpenuhinya unsur Subjektif sahnya perjanjian maka suatu perjanjian bukan batal demi hukum tetapi dapat dimintakan pembatalan oleh salah satu pihak. Tentang perjanjian yang tidak memenuhi syarat subjektif yang menyangkut kepentingan seseorang, dalam hal ini Plt Direksi dianggap oleh undang-undang sebagai pihak yang tidak cakap dalam mewakili PT Angkasa Pura dalam melaksanakan perjanjian, karena Direksi Pelaksana tersebut tidak sah kedudukannya untuk menjalankan fungsi perwakilan untuk perusahaan. Kekurangan syarat subjektif ini tidak begitu saja dapat diputuskan hakim sehingga dibutuhkan pembuktian. Mengacu pada ketentuan pasal 1265 KUHPerdata bahwa suatu syarat batal adalah syarat yang apabila dipenuhi menghentikan perikatan, dan membawa segala sesuatu kembali, pada keadaan semula, seolah-olah tidak pernah ada suatu perikatan. Berdasarkan penjelasan pasal 1266 KUHPerdata, syarat batal dianggap selalu dicantumkan dalam persetujuan-persetujuan yang bertimbal balik manakala salah satu pihak tidak memenuhi kewajibannya. Dalam hal yang demikian persetujuan tidak batal demi hukum tetapi pembatalan harus dimintakan kepada hakim. ${ }^{10}$

Berdasarkan penjelasan syarat sah perjanjian yang diatur didalam Pasal 1320 KUHPerdata maka yang menjadi tidak terpenuhinya unsur sahnya perjanjian yang diwakilkan oleh Direksi Plt yang diangkat oleh Dewan Komisaris adalah tidak terpenuhinya unsur subjektif, dimana Pelaksana Tugas Direksi bukanlah pihak yang cakap atau yang sah dalam mewakili PT Angkasa Pura untuk melakukan perbuatan hukum dengan pihak ketiga.

Syarat sahnya perjanjian kedua yang terdapat pada Pasal 1320 KUH Perdata adalah kecakapan untuk membuat perikatan. Dari kata "membuat" perikatan dan perjanjian, terdapat unsur "niat" (sengaja) dan yang demikian itu memang cocok untuk "perjanjian", yang merupakan tindakan hukum ${ }^{11}$. Menurut J. Satrio istilah yang tepat untuk menyebutkan syaratnya perjanjian yang kedua ini adalah kecakapan untuk membuat perjanjian. Kecapakan untuk melakukan perbuatan hukum pada umumnya diukur dari standar, berikut ini:

a. Person (pribadi), diukur dari standar usia kedewasaan (meerdejaring);

b. Rechspersoon (badan hukum), diukur dari aspek kewenangan (bevoegheid).

Selain kecakapan yang bertindak dari segi umur yaitu kecakapan yang ditujukan pada orang (person), kecakapan juga ditujukan kepada badan hukum (rechs person) yaitu dengan kapasitas atau wewenang pihak dalam melakukan perbuatan hukum. Di dalam UUPT telah ditentukan siapa (organ perseroan) yang berhak dan bertanggung jawab dalam mewakili perusahaan untuk melakukan pengurusan dan kepentingan perusahaan baik di dalam maupun di luar pengadilan (sesuai dengan ketentuan UUPT pasal 1 angka 5.

Untuk itu pengangkatan Plt direksi berdasarkan Anggaran Dasar yang tidak sah atau bertentangna dengan UUPT dan UUBUMN mengakibatkan perjanjian yg dibuat dengan pihak ketiga tidak memenuhi unsur subyektif yaitu tidak cakap, karena plt direksi dianggap tidak berwenang melakukan perbuatan hukum karena pengangkatannya tidak sah.

Dengan demikian, tidak terpenuhinya unsur subjektif dalam suatu perjanjian, maka perjanjian tersebut dapat dimintakan pembatalan oleh pihak yang merasa dirugikan akibat dari perjanjian tersebut.

\section{b. Akibat Hukum ketentuan Pengangkatan PIt. Direksi oleh Dewan Komisaris Pada Ang- garan Dasar PT Angkasa Pura dikaitkan dengan pengaturan Pengangkatan Direksi yang diatur dalam UU BUMN dan UUPT}

\footnotetext{
${ }^{10}$ Subekti.(1990). Hukum Perjanjian. Jakarta: Intermasa, hlm 17

${ }^{11}$ J. Satrio.(1999). Hukum Perikatan: Perikatan yang lahir dari perjanjan buku II. Bandung: Alumni, hlm.40
} 


\section{Pengangkatan Direksi dalam UUPT}

Kedudukan Direksi memiliki fungsi pengurusan dan perwakilan terhadap segala tindakan dan perbuatan hukum perseroan. Mengingat betapa pentingnya peran direksi dalam suatu perseroan, maka UUPT mengatur dengan sangat jelas ketentuan mengenai direksi yaitu: Pasal 1 ayat (5) Undang-Undang No. 40 Tahun 2007 Tentang Perseroan Terbatas mendefinisikan direksi sebagai organ perseroan yang berwenang dan bertanggung jawab penuh atas pengurusan dan tujuan perseroan serta mewakili perseroan, baik di dalam maupun di luar pengadilan sesuai dengan ketentuan Anggaran Dasar ${ }^{12}$.

UUPT juga mengatur secara rinci menkanisme pengangkatan direksi yang mana dituangkan dalam Pasal 94 UUPT.

Keberadaan Pasal 94 UUPT menjelaskan bahwa Direksi hanya dapat diangkat melalui RUPS, kewanangan RUPS ini adalah mutlak tidak dapat diwakilkan atau digantikan oleh organ lain.

\section{Pengangkatan Direksi dalam UU BUMN}

BUMN merupakan salah satu pelaku kegiatan ekonomi dalam perekonomian nasional berdasarkan demokrasi ekonomi. Pengaturan mengenai BUMN telah mengalami beberapa perubahan dan yang berlaku saat ini adalah Undang-Undang No 19 tahun 2003 tentang Badan Usaha Milik Negara, yang sesuai pasal 1 ayat (1) menyebutkan pengertian BUMN adalah: "Badan Usaha Milik Negara, yang selanjutnya disebut BUMN, adalah badan usaha yang seluruh atau sebagian besar modalnya dimiliki oleh negara melalui penyertaan secara langsung yang berasal dari kekayaan negara yang dipisahkan."

Pengurusan dan pengawasan perseroan BUMN dilakukan secara cermat dan hati-hati, dengan membuat peraturan pelaksana sebagaimana diatur dalam Peraturan Pemerintah No.45 tahun 2005 tentang Pendirian, Pengurusan, Pengawasan, dan Pembubaran BUMN, serta Anggaran Dasar Perusahaan (PP BUMN) sesuai dengan UU dan PP dimaksud.

\section{1) Bentuk BUMN}

Berdasarkan ketentuan Pasal 9 UU BUMN, dinyatakan BUMN terdiri dari:

1.1) Persero yaitu BUMN berbentuk perseroan terbatas yang modalnya terbagi dalam saham yang seluruh atau paling sedikit 51\% (lima puluh satu persen) sahamnya dimiliki oleh Negara Republik Indonesia yang tujuan utamanya mengejar keuntungan.

1.2) Perusahaan Umum (Perum), yaitu Perum adalah BUMN yang seluruh modalnya dimiliki negaradantidakterbagiatassaham,yangbertujuanuntukkemanfaatanumumberupapenyediaan barang dan/atau jasa yang bermutu tinggi dan sekaligus mengejar keuntungan berdasarkan prinsip pengelolaan perusahaan.

\section{2) Organ BUMN Persero}

Organ persero diatur didalam Pasal 13 UU BUMN yaitu:

1) RUPS; 2) Direksi; dan 3)Dewan Komisaris.

Pengaturan mengenai direksi diatur dalam Pasal 15 sampai dengan Pasal 26 UU BUMN, dimana dalam Pasal 15 berbunyi sebagai berikut:

Ayat (1) : "pengangkatan dan pemberhentian Direksi, dilakukan oleh RUPS"

Ayat (2): "dalam hal menteri bertindak selaku RUPS, pengangkatan dan pemberhentian direksi ditetapkan oleh Menteri”

${ }^{12}$ Indonesia, Undang-Undang Republik Indonesia tentang Perseroan Terbatas, UU No.40 Tahun 2007, LN No.106 Tahun 2007, Pasal 1 angka 5. 
Sama halnya dalam UUPT, kewenangan direksi perseroan BUMN adalah untuk menjalankan 2 (dua) fungsi : a. Sebagai pengurus perseroan; dan b. Sebagai perwakilan perseroan.

Direksi bertanggung jawab atas pengurusan perseroan dengan itikad baik. Tanggung jawab direksi melekat penuh secara probadi atas kerugian perseroan, apabila anggota direksi yang bersangkutan bersalah atau lalai dalam menjalankan tugasnya. ${ }^{13}$

Pada PP BUMN diatur mengenai Petunjuk Pelaksanaan UU BUMN yang menetapkan mengenai pengangkatan direksi, khususnya Pasal 19 ayat (3) yang berbunyi : "Dalam anggaran dasar diatur ketentuan mengenai pengisian sementara jabatan Direksi yang kosong atau dalam hal direksi diberhentikan sementara atau berhalangan"

Dengan adanya ketentuan Pasal 19 ayat (3) PP BUMN yang telah disebutkan di atas, maka memberikan kesempatan kepada BUMN berbentuk PT untuk mengatur pelaksanaan pengangkatan direksi yang lowong dalam anggaran dasarnya. Namun, pemberian kewenangan kepada perseroan untuk mengatur bagaimana mengangkat direksi yang jabatannya sedang lowong semestinya tidak bertentangan dengan ketentuan peraturan perundang-undangan.

\section{Pengangkatan PIt. Direksi dalam Anggaran Dasar PT Angkasa Pura (seluruh saham- nya dimiliki oleh BUMN)}

Pemakaian kata Pelaksana Tugas Direksi (Plt Direksi) pada dasarnya memang tidak dikenal baik di dalam UUPT maupun UUBUMN, karena dalam kedua UU tersebut hanya menyebutkan Direksi. Akan tetapi dalam pelaksanaan suatu perusahaan perlu diangkat Plt Direksi untuk mengisi jabatan yang lowong apabila anggota Direksi yang yang bersangkutan sedang cuti dalam waktu tertentu ataupun sedang melakukan dinas ke luar kota, hal ini diperlukan agar segala tanggung jawab perusahaan dalam hal ini suatu BUMN persero ini tetap dapat melaksanakan hak dan kewajibannya.

Di dalam Anggaran Dasar PT Angkasa Pura Persero, khususnya pasal 10 ayat $26 \mathrm{~b}$ ditegaskan bahwa Plt Direksi menjalankan pekerjaan anggota Direksi yang lowong tersebut dengan kekuasaan dan wewenang yang sama, artinya jabatan Plt Direksi bertindak sebagai Direksi yang diisi jabatannya.

Berdasarkan Anggaran Dasar tersebut di atas, khususnya pasal 10 ayat (26) b., terdapat kalimat "...maka dewan komisaris menunjuk salah seorang anggota direksi lainnya atau RUPS menunjuk pihak lain selain anggota direksi yang ada... dst”. Hal tersebut dapat diartikan bahwa untuk mengisi jabatan direksi yang lowong, dapat dilakukan dengan cara:

a. Dewan komisaris menunjuk salah seorang anggota direksi lainnya, atau

b. RUPS menunjuk pihak lain selain anggota direksi yang ada.

Tegasnya dalam kondisi di atas bahwa pengangkatan Direksi perseroan yang lowong dimungkinan untuk diangkat oleh selain RUPS, yaitu oleh Dewan Komisaris. Sedangkan berdasarkan ketentuan UUPT dan UU BUMN dinyatakan dengan tegas bahwa pengangkatan direksi hanya dapat dilakukan melalui RUPS. Sesuai UUPT dan UUBUMN keabsahan pengangkatan anggota direksi hanya melalui keputusan RUPS, sebagai organ yang memegang kekuasaan tertinggi dimana kekuasaan dan wewenang tersebut tidak dapat diwakilkan atau dilimpahkan kepada organ lainnya, termasuk pelimpahan kepada Dewan Komisaris.

Berdasarkan uraian mengenai pengangaktan direksi pelaksana dalam UUPT, UU BUMN dan Anggaran Dasar PT Angkasa Pura terdapat ketidakselarasan yang mana Anggaran Dasar PT Angkasa Pura yang mengatur bahwa pengangkatan pelaksana Direksi dapat dilakukan oleh organ selain RUPS, yaitu Dewan Komisaris. Yang mana secara jelas pada Pasal 94 ayat (1) UUPT ditegaskan bahwa yang berhak mengangkat direksi adalah RUPS serta didalam Pasal

${ }^{13}$ Iksan Lubis dan Neneng Oktarina.(2018). Perlindungan hukum terhadap direksi yang dberhentikan tanpa melalui Rapat Umum Pemegang Saham (Studi pada PT Sumber Andalan Mandiri (SAM)". Padang: Jurnal Univerisitas Andalas, hlm 3. 
15 ayat (1) UU BUMN diatur bahwa yang berhak mengangkat dan memberhentikan direksi adalah RUPS, meskipun PP BUMN didalam Pasal 19 ayat (3) memberikan kewenangan kepada perseroan untuk mengatur dan mengangkat direksi yang posisinya lowong didalam anggaran dasar, namun pada prinsipnya Anggaran dasar tidak diperkenankan untuk melanggar ketentuan pengangkatan direksi yang telah diatur oleh peraturan perundang-undangan yang lebih tinggi daripadanya, seharusnya UUPT, UU BUMN, dan PP BUMN menjadi acuan dan menjadi tolak ukur bagi PT Angkasa Pura dalam merumuskan anggaran dasarnya agar terjadi keselarasan antara peraturan perundang-undangan yang satu dengan yang lain, maka dengan demikian akibat hukum PT Angkasa Pura karena Anggaran Dasarnya tidak sesuai dengan peraturan perundang-undangan adalah menyebabkan Perbuatan hukum yang dilakukan PT Angkasa Pura mengandung cacat formil yakni tidak sesuai dengan hukum yang berlaku.

Sebagaimana telah penulis jelaskan dalam Teori Kepastian Hukum menurut Gustav Radbruch dalam buku Muhammad Erwin bahwa sesuatu yang dibuat pasti memiliki cita atau tujuan. Kepastian hukum menghendaki adanya upaya pengaturan hukum dalam perundangundangan yang dibuat oleh pihak yang berwenang dan berwibawa, sehingga aturan-aturan itu memiliki aspek yuridis yang dapat menjamin adanya kepastian bahwa hukum berfungsi sebagai suatu peraturan yang harus ditaati. Untuk itu demi tercapainya kepastian hukum dalam hal pengangkatan pelaksana tugas direksi (Plt Direksi) ini diperlukan aturan yang lebih jelas sehubungan dengan tugas dan wewenangnya serta pengaturan dalam suatu Anggaran Dasar Perseroan agar tidak bertentangan dengan Undang-Undang Perseroan Terbatas.

Menurut analisis penulis jika dikaitkan dengan teori kepastian hukum menurut Gustav Radburch yang menyatakan menjamin adanya kepastian bahwa hukum berfungsi sebagai suatu peraturan yang harus ditaati, maka seharusnya peraturan yang ada didalam Anggaran Dasar tidak boleh bertentangan dengan peraturan Undang-Undang yang berada diatasnya sehingga mengakibatkan peraturan yang ada di dalam Anggaran Dasar itu menjadi tidak sah, karena untuk mewujudkan kepastian hukum, peraturan yang ada harus ditaati.

Dengan adanya pertentangan antara peraturan hukum yang satu dengan yang lainnya terkait pengangkatan direksi dalam perseroan milik BUMN, yaitu ketentuan yang berlaku di dalam UUPT dan UUBUMN serta PP No.45 tahun 2005 tentang Pendirian, Pengurusan, Pengawasan, dan Pembubaran BUMN, dengan Anggaran Dasar Perseroan PT Angkasa Pura (Persero) dimana Anggaran Dasar suatu perusahaan merupakan suatu perjanjian yang dibentuk berdasarkan petunjuk dari peraturan pemerintah sehingga peraturan yang terdapat didalam Anggaran Dasar tidak boleh bertentangan dengan peraturan yang ada diatasnya. Hal ini sesuai dengan asas Lex superior derogat leg inferior yang menyatakan bahwa hukum yang lebih tinggi (lex superior) mengesampingkan hukum yang rendah (leg inferior) sehingga menurut penulis apabila ada perbedaaan pengaturan dalam suatu Anggaran Dasar dengan peraturan Perundang-undangan maka yang berlaku adalah Peraturan Perundang-Undangan.

Adapun akibat hukum pengangkatan Plt Direksi berdasarkan Anggaran Dasar PT Angkasa Pura Persero menjadi tidak sah karena bertentangan dengan peraturan perundang-undangan yang berada diatasnya dalam hal ini adalah UUPT, UUBUMN, dan PP. Untuk itu diperlukan perubahan terhadap peraturan Anggaran Dasar tersebut agar tidak bertentangan dengan peraturan diatasnya sehingga terwujud suatu kepastian hukum.

\section{KESIMPULAN}

Terdapat pertentangan antaraAnggaran Dasar PT. Angkasa Pura mengenai penangkatan Direksi yang lowong pada BUMN dengan Undang-Undang Nomor 19 Tahun 2003 tentang BUMN dan Undang-Undang Nmor 40 tahun 2007 tentang Perseroan Terbatas, dengan demikian mekanisme mengenai pengangkatan dan pemberhentian Direksi harus mengikuti ketentuan 
yang diatur dalam UUPT, dan UUPT dengan tegas dinyatakan bahwa yang dapat mengangkat direksi hanyalah RUPS. Dengan bertentangannya pengangkatan PLT Direksi oleh Dewan komisaris, maka dapat berakibat hukum terhadap perbuatan hukum yang dilakukan oleh PLT Direksi tersebut karena Anggaran Dasarnya tidak sesuai dengan peraturan perundang-undangan adalah menyebabkan Perbuatan hukum yang dilakukan PT Angkasa Pura mengandung cacat formil yakni tidak sesuai dengan hukum yang berlaku

\section{DAFTAR PUSTAKA}

Freddy harris dan Teddy Anggoro.(2010). Hukum Perseroan Terbatas: Kewajiban Pemberitahuan oleh Direksi. Bogor: Ghalia Indonesia.

Garner, Bryan A.(2012). Black’s Law Dictionary. Minnesota: West Group, Eagen.

Chatamarrasjid Ais.(2004). Penerobosan Cadar Perseroan dan Soal-soal Aktual Hukum Perusahaan. Bandung: Citra Aditya Bakti.

Amiruddin \& Zainal Asikin.(2006). Pengantar Metode Penelitian Hukum. Jakarta: Raja Grafindo Persada.

Miriam Budiarjo.(1998). Dasar-dasar ilmu politik. Jakarta: Gramedia Pustaka Utama.

Salim dan Nurbani.(2013). Penerapan Teori Hukum Pada Penelitian Tesis dan Desertasi. Depok: Rajagrafindo Persada.

Abdul Rasyid Thalib.(2006). Wewenang Mahkamah Konstitusi dan Aplikasinya dalam sistem ketatanegaraan Republik Indonesia, Bandung: Citra Aditya Bakti.

Claudia Brigita Kilis.(2015). Tanggung Jawab Dewan Komisaris PT dalam melaksanakan pengawasan terahdap Direksi menurut Undang-Undang no. 40 tahun 2007, Manado: Jurnal Universitas Sam Ratulangi.

Nyulistyowati Suryani.(2015). Hukum Perusahaan. Jakarta: Karunika.

Subekti.(1990). Hukum Perjanjian. Jakarta: Intermasa.

J. Satrio.(1999). Hukum Perikatan: Perikatan yang lahir dari perjanjan buku II. Bandung: Alumni

Indonesia, Undang-Undang Republik Indonesia tentang Perseroan Terbatas, UU No.40 Tahun 2007, LN No.106 Tahun 2007, Pasal 1 angka 5.

Iksan Lubis dan Neneng Oktarina.(2018). Perlindungan hukum terhadap direksi yang dberhentikan tanpa melalui Rapat Umum Pemegang Saham (Studi pada PT Sumber Andalan Mandiri (SAM)”. Padang: Jurnal Univerisitas Andalas. 